\title{
Comparing Capitalisms: Debates, Controversies and Future Directions
}

Accepted for publication in Sociology.

Authors:

Geoffrey T. Wood, Western University, Ontario, Canada

Matthew M. C. Allen, The University of Essex, UK

Corresponding author:

Matthew M. C. Allen

Professor of International Business and Strategy, and Head of Management Science and

Entrepreneurship Group

Essex Business School

Elmer Approach

Southend-on-Sea

Essex

SS1 1LW

UK

Matthew.allen@essex.ac.uk 


\begin{abstract}
Various strands of the comparative capitalisms (CC) literature agree that the advanced economies have liberalized in recent years, bringing with it rising income and wealth inequality and job insecurity; although these perspectives differ in important ways, there is much common ground between them to explain this heightened level of inequality and insecurity. Through reviewing contributions to three key CC perspectives since 2007/2008, we argue that they have tended to focus on developments in co-ordinated market economies, leading to a neglect of growing structural crises in liberal market economies, which have contributed to the UK and the US entering uncharted socio-political waters. We extend recent work that emphasizes how variation between countries in labourmarket institutions, different corporate forms and states' fiscal policies help to explain income and wealth inequality to highlight future research agendas that seek to combine more systematically these institutional areas to explain social inequalities, workers' experiences and socio-political crises within capitalist systems.
\end{abstract}

Keywords: comparative capitalism; economic sociology; inequality 


\section{Introduction}

Income inequality and job insecurity have increased in many developed economies, especially since the 2007/2008 financial crisis (Thelen, 2014). The persistent differences in inequality within and between developed economies and, more recently, right-wing populist backlashes, have highlighted the need for fuller understandings of the relationship between different forms of capitalism, social equity and crisis (Dorling, 2018; Hall, 2015b; Morgan, 2016; O’Reilly et al., 2016; Wilkinson and Pickett, 2009).

We review the relevant comparative capitalisms (CC) literature since the crisis. Existing studies have tended to focus either on how economies characterized by nonmarket forms of co-ordination are likely to become more de-regulated (Baccaro and Benassi, 2014, 2017; Hall and Thelen, 2009; Streeck, 2014b; Thelen, 2014; Whitley, 2012) or the global spread of neo-liberalism (Jessop, 2012; Streeck, 2012; cf. Pradella, 2017). Yet, neo-liberalism brings with it many contradictions and problems. Sandel (2012) highlights the moral and practical limits to the extension of markets: within many developed societies, markets have extended into a number of areas where previously their influence was more limited, including education, health, government, law, and family life. In turn, this undermines those moral and civic goods that make markets possible (Sandel, 2012).

However, mainstream politicians have often been unwilling or unable to offer policy alternatives to liberalization (Kuttner, 2007), leaving a large proportion of the electorate demonstrably worse off (Kalleberg, 2009), and enabling populists to gain influence and/or power (Hopkin, 2017). This implies that, if co-operative features of markets recede and/or that a specific manifestation of capitalism does not deliver for many, the entire system may be challenged (Hopkin, 2017; Kalleberg, 2009). Furthermore, capitalist systems that have more co-operative features may be more 
sustainable as they have a greater ability, relative to other capitalist forms, to better reconcile shareholder and stakeholder interests (Dore, 2000).

However, much of the CC literature tends to downplay how institutions associated with the most liberal market economies, the UK and the US (Gamble, 2014), can lead to particularly marked increases in equality and insecurity (Hall, 2015b; Hay, 2013; Hay and Payne, 2015; cf. Williams, 2017), and, potentially, socio-political instability (O'Reilly et al., 2016). For instance, the UK and US display the highest levels of inequality (see figures 1 and 2 below) and high levels of wealth inequality (Alvaredo et al., 2018). Indeed, rather than most advanced economies defaulting to neoliberalism, the UK and US have entered uncharted socio-political waters, raising questions about their relative stability. This has significant implications for capitalism as a global phenomenon, especially as the liberal market economy (LME) model has been upheld as the gold standard for emerging markets (Dewenter and Malatesta, 2001). However, evolving capitalisms in state socialist countries, such as China, may continue on a distinct trajectory (Zhang and Whitley, 2013).

We argue that there is a need to explain not only changes in the levels of income inequality and job (and occupational) security, in general, but also differences between LMEs and other types of market economy and, indeed, between LMEs themselves. By focusing on overall growth and employment, the existing literature tends to downplay systemic outcomes that still leave many (or, indeed, most) worse off, in turn making for socio-political problems (Lavery, 2018). In other words, the recursive relationship between inequality experienced by individuals and societal changes is important (Halford and Strangleman, 2009; Strangleman, 2017; Watson, 2009), and, indeed, may eclipse broadly positive 'headline' figures around growth. We build on existing work that emphasizes the influence of labour-market systems (Thelen, 2014, 2019) as well as 
different corporate forms (Kristensen and Morgan, 2018) and the broad role of the state (Morgan, 2016) to put forward a research agenda that more systematically captures these explanatory factors.

\section{Boundaries of Analysis}

Work on capitalism and comparative capitalisms has a long history (Giddens, 1970; Lane, 1989; Lincoln and Kalleberg, 1990; Melling, 1991). We use the term 'CC' to encompass work that adopts a largely geographical perspective and that draws on socioeconomic analysis to compare, inter alia, variations in formal and informal regulation, the nature of firms, their competitive strengths, and the associated cross-country patterns of inequality and comparative advantages (Jackson and Deeg, 2008). The three approaches we review are: 1) the Varieties of Capitalism (VoC) (Hall and Soskice, 2001; Jackson and Deeg, 2008) and the related business systems theory (BST) (Whitley, 1999, 2003, 2012), 2) historical institutionalism (HI) (Steinmo and Thelen, 1992; Thelen, 1999), and 3) the régulationist literature, and its recent developments and extensions, including the Social Systems of Production (SSP) approach (Hollingsworth and Boyer, 1997) and the literature on variegated capitalism (Jessop, 2012). We recognize that the differences between these three approaches are not always as distinct in practice as we propose here, and that individual analyses do not necessarily fit consistently or neatly into one of our three categories (Wood, 2013). The primary focus of this article is on capitalisms within the developed world; however, where salient, we make reference to other forms of capitalism.

The CC perspective differs to mainstream economics and finance approaches (for example, Djankov et al., 2003), which tend to adopt a narrow, 'uni-dimensional' view of institutions and their influences, centring on the institutional foundations of 
private property rights and assuming that this single institutional feature over-rides all others (Boyer, 2011; Whitley, 2003).

We examine the emphases these frameworks place on different explanatory factors and highlight the implications for societal inequalities and broader sociopolitical stability. We provide, in Figures 1 and 2, key measures of income inequality; such measures are important indicators that often form part of broader analyses (Halford and Savage, 2017; Wilkinson and Pickett, 2009). We recognize, however, that such measures alone do not capture all nuances of social inequality (Goldthorpe, 2010). Both figures show Gini coefficients before and after taxes and transfers. Figure 1 shows data for 2008; Figure 2, 2016. Both figures reveal that, even though the UK and the US did not have the highest levels of income inequality before taxes and transfers, they did after, indicating that their governments play a relatively limited role in reducing marketbased income inequality. This role has persisted and the current $\mathrm{CC}$ literature does not fully consider it when explaining income and wealth inequalities.

Figure 1 about here

Figure 2 about here

\section{Methods}

We focus on the dynamics of individual capitalist systems as well as capitalism per se in developed economies. We have stopped short of conducting a full systematic review, 
but have, nevertheless, attempted to do justice to the CC literature since 2007/8; during this period a re-assessment of capitalism has taken place (Morgan, 2016; Streeck, 2016; Thelen, 2019). We seek to capture how themes within three strands of the CC literature have evolved since the end of the 'Great Moderation', which lasted from approximately 1989 until 2007/2008 (Coates, 2015). Generally, sustained economic growth, buoyant labour markets and rising living standards in advanced capitalist economies characterized the Great Moderation, leading the CC literature to focus on capitalist variation rather than capitalist commonalities (Coates, 2015: 18-20).

\section{VoC and BST Frameworks}

Drawing together key strands of comparative political economy, an influential 2001 edited collection first laid out the VoC framework, which combines an analysis of institutions and societies with an assessment of rational economic actors' strategic interactions (Hall and Soskice, 2001). Focusing on how institutions generate and sustain trust and enhance knowledge within economies, business systems theory is more explicitly sociological (Whitley, 1999; Hall and Soskice 2001). Both perspectives have traditionally focused on the diversity of firms, production and their capabilities and how institutions help or hinder companies solve particular co-ordination problems rather than the dynamics of capitalism or the consumption of finished products and services; by doing so, they identify patterns of firm behaviour within particular national archetypes (Hall and Soskice, 2001; Whitley, 1999).

This does not mean that all firms within a particular national economy will behave the same; however, the diversity of company forms and capabilities will be bounded (Wood et al., 2009). Although differences exist between the two approaches, both place growth within the context of relative stakeholder well-being; both, therefore, 
differ from orthodox economic approaches to comparative institutional analysis (Djankov et al., 2003).

Initially, both perspectives viewed institutions and patterns of economic organization as relatively stable (Boyer, 2005; Hall and Thelen, 2009; Thelen, 2014). When institutional change did occur, the VoC and BST perspectives focused on how diverse groups of collective actors responded to exogenous challenges, such as the internationalization of markets, advances in technology and the collapse of communism (Hall and Soskice, 2001: 56-60; Morgan, 2005; Whitley, 2012). They did not incorporate developments from within the institutional system itself into their analyses (Boyer, 2005; Streeck, 2012).

Some recent contributions, however, highlight 1) how collective actors continuously test the limits of existing institutions to maximize the distributive benefits accruing to them or the coalition that they represent, 2) the role of financialization in institutional change and 3) the recursive effects of greater liberalization and austerity on future liberalization (Kristensen and Morgan, 2018; Morgan, 2016). This important development highlights capitalism's dynamic qualities (Hall and Thelen, 2009; Morgan, 2016; cf. Wood and Lane, 2012) and recognizes, therefore, that any dominant set of institutional arrangements is always conditional and contested.

The key issue here is the argument that endogenous and exogenous factors are likely to undermine particular institutions, such as labour-market regimes and corporategovernance codes, that do not conform closely to liberal-market precepts, leading, typically, to conclusions that emphasize the weakening of institutional systems that enable obligational forms of contracting and 'non-arm's length' modes of exchange (Morgan, 2014, 2015; Whitley, 2012). 
Whilst some of this research does not assess the ramifications of increasingly liberalized forms of capitalism for different forms of inequality (Morgan, 2015; Whitley, 2012), some does, arguing inequality is increasing in many countries (Morgan, 2016; Morgan and Kristensen, 2014). This latter work typically builds on existing theories. First, key arguments draw on Polanyi's (2001 [1944]) notion of a 'double movement' to highlight how the state, reflecting societal pressures, uses funds from taxation and borrowing to provide social and economic benefits to individuals based on citizenship rights rather than market power (Morgan, 2016: 1; Morgan and Kristensen, 2014). Second, these arguments draw on Weberian and Polanyian insights to emphasize how some actors seek to extend the market's breadth and depth (Morgan, 2016; Morgan and Kristensen, 2014; Morgan and Whitley, 2012). Finally, these contributions cite Marx and Schumpeter to explain how markets and competition develop dynamically, often leading to increased inequality (Morgan, 2016).

By drawing on Polanyi to highlight potential 'double movements' and by emphasizing the dynamism of capitalism more heavily than they did, recent VoC and BST contributions resemble $\mathrm{HI}$ ones. However, unlike the $\mathrm{HI}$ and regulation approaches, the $\mathrm{VoC}$ and $\mathrm{BST}$ perspectives tend also to highlight how variation in corporate-governance regulations influences the types of firm that exist in different countries and their abilities to pursue particular objectives, helping to explain differences in societal outcomes, including income inequalities (Kristensen and Morgan, 2018; Morgan and Kristensen, 2014).

\section{Historical institutionalism}

HI tends to focus on particular policy areas within broader political structures, often seeking to explain secular political processes (Steinmo and Thelen, 1992; Thelen, 
1999). It analyses how collective actors, such as businesses, business organizations and unions, initiate and contest political developments within existing political structures and policies, such as decision-making procedures, the constitution of political parties and electoral systems (Thelen, 1999). Institutions, therefore, not only structure actors' context, but also their understandings of problems and potential solutions (Steinmo and Thelen, 1992; Thelen, 1999). The HI literature tends, therefore, to focus overtly on political contests, resulting, we argue, in the inadvertent downplaying of crises that are more likely to affect the most liberal forms of capitalism than they are other forms of capitalism in developed economies (Deeg, 2012).

Political contests do not necessarily mean that economic and financial elites are always able to determine institutional regimes (Emmenegger and Marx, 2011). Instead, they must compromise and are likely to seek to adapt those compromises in their favour, whenever possible, to promote less constrained market relations, both within and beyond the workplace (Thelen, 2012). However, the 2008 crisis has led influential historical institutionalists to conclude that national institutional arrangements that mediate and inhibit 'free' labour markets are progressively unwinding, with all nations, even if at different paces, entering an era characterized by unmediated market relations (Streeck, 2013; Thelen, 2014, 2019).

Polanyian notions of double movements influence such arguments (Polanyi, 2001; Streeck, 2014a): periodically, political settlements seek to constrain the negative consequences of unbridled markets; these are then, in turn, challenged by counter pressures (Streeck, 2014a; Thelen, 2014). This means that there can never be a durable final institutional settlement (Streeck, 2012); capitalism develops along a dynamic path between state and market, and each period of state or market mediation is fundamentally different to preceding phases (Streeck, 2014a). 
However, the emphasis on these double movements differs in HI work. Whilst $\mathrm{HI}$ analyses conclude that greater marketization is occurring, some work focuses on capitalism and other work highlights the potential for some actors to restrict the growth of the market. For instance, Streeck, (2014b) implicitly relies on a non-agential model of capitalism to explain socio-economic outcomes: it is capitalism itself that pursues relatively unencumbered and autogenic expansion (cf. Polanyi, 2001). Other accounts draw to a greater extent on Polanyi's (2001) notion of a 'double movement' to stress how 'society' may be able to act as a possible brake on increased marketization (Baccaro and Benassi, 2017; Benassi et al., 2016; Crouch, 2013, 2014). These latter studies tend, however, to argue that societies are largely unable to stop the erosion of institutions that prevent 1) the commodification of many forms of work and economic activity (Kinderman, 2017; Regini, 2014), and, consequently, 2) increased inequality (Greer and Doellgast, 2017); subsequently, they typically view institutional change and greater marketization as a process immanent within capitalism (Baccaro and Benassi, 2017; Crouch, 2013, 2016; Streeck, 2009, 2014a), making it difficult to explain variation in income inequalities both between and within different types of capitalism.

Such arguments also echo, in part, Marxian and Weberian logics about developments within capitalism that highlight how production or capitalism can become an end in itself rather than a means either to demonstrate one's religious piety or to meet immediate material needs, leading to a lack of choice for individuals but to become a part of the capitalist system and the commodification of many forms of labour (Parsons, 1929: 43; Watson, 2009; Weber, 2001: 123-124).

These assessments often stem from a focus on Germany (Baccaro and Benassi, 2014, 2017; Kinderman, 2017; Streeck, 2009). The close scrutiny of any type of capitalism is likely to make some change or shortfall visible. Some HI literature focuses 
on Germany and its experience leading up to, during, and after the so-called Hartz reforms. These reforms changed labour-market and social-welfare policies significantly, and they followed recommendations by the Committee for Modern Services in the Labour Market, chaired by Peter Hartz (Seeleib-Kaiser, 2016). By focusing on Germany, such HI work may, inadvertently, have over-estimated market liberalism's robustness and under-estimated the relative durability of the German model's core features. For instance, recent work has highlighted how large German industrial foundations and families that own firms have closed ranks to ward off relatively shorttermist UK and US institutional investors, even as other interests have continued to push for liberalization (Haberly, 2014).

When research focuses on other countries, the analysis often concentrates on how relevant collective actors cannot prevent the weakening of unions and collective wage bargaining, leading to increases in income inequality (Amable, 2017; Baccaro and Howell, 2017; Thelen, 2019). There has been a tendency for historical institutionalists to see change as primarily a political process, led by defectors from a particular institutional order who would gain materially from the changes they propose (Amable, 2017; Crouch, 2016; Kinderman, 2017). This analytical focus can potentially explain pre-tax and pre-transfer income inequality, but cannot address post-tax and post-transfer inequality. Such work, therefore, downplays how the state influences inequality, and, as Durkheim, (1960: 378, [1893]) noted over a century ago, how existing wealth inequalities influence earnings opportunities (see also Bukodi and Paskov, 2018).

Moreover, HI often suggests that any model of capitalism is likely to be unsustainable precisely because it is capitalistic (Baccaro and Howell, 2017; Streeck, 2014a, 2014b), downplaying the particular problems associated with liberal forms of capitalism and how fiscal policies influence levels of market-based income inequality. 
However, Thelen's (2019) work stresses analysing labour-market institutions, such as unions and collective wage bargaining, and their variation across countries to explain employment insecurity and, by extension, income inequality.

\section{The Régulation Approach}

We define the régulation approach broadly to encompass those who contribute explicitly to it as well as those who adopt a similar, but different perspective and who may use alternative labels, such as the Amsterdam School (Boyer, 1990). It focuses on the links between the industrial paradigm (the mode governing the technical and social division of labour), mode of régulation (that looks at the factors that influence individuals' behaviour), accumulation or growth regime (the typical patterns of consumption and production as well as how a national economy, typically, grows), and modes of development (when the former three work together for a sufficient period of time to ensure a long wave of growth) (Boyer, 2005, 2011; Jessop, 1990, 2001: xxvii).

More specifically, a mode of regulation is the '[en]semble of norms, institutions, social networks and patterns of conduct that can stabilize an accumulation regime', and the latter 'a complementary pattern of production and consumption' (Jessop, 1990. p. xxvii). Both are spatially and temporally confined, and the former is of very much shorter duration and scale than the traditional Marxist concept of a mode of production. It emphasizes the inherently unstable nature of all forms of capitalism (Boyer, 2005, 2010), with sets of institutional arrangements providing temporary, contingent, and spatially and temporally specific 'fixes' (Amable, 2016). This, in turn, highlights the endogenous characteristics of many instances of institutional change (Boyer, 2005, 2011; Jessop, 2012). The approach also highlights the inter-connections between 
different types of capitalism (Boyer, 2011) and how this can lead to increases in inequality in some countries (Jessop, 2014c).

Rather than seeing the firm as the arena in which embedded formal and informal rules are simply enacted and reconstituted, drawing on its part-Althusserian ancestry (Lipietz, 1993), the régulation approach accords a central role to the process of production and the inherent tensions it embodies (Boyer, 1990). Indeed, régulation theory initially focused on explaining the conditions under which Fordist modes of production and consumption provided stable growth for many years, but ultimately declined (Boyer, 2005; Jessop, 2012).

As régulation theory builds from the idea that capitalist systems are inherently dynamic and prone to crisis (Boyer, 2000; Jessop, 1997), it was quicker than the VoC and BST approaches to identify and analyse financialization (Boyer, 2000, 2013b), which continues to develop (Davis and Kim, 2015; Jessop, 2014b). Although an emphasis on financialization may suggest greater liberalization is ineluctable, the régulation approach did, initially, consider the possibility of new institutional fixes emerging that might nurture and replicate more co-operative forms of work organization (Boyer, 2004).

Indeed, Boyer's earliest work on finance explored how financialization might underpin a new wave of growth; however, this work concluded that, at most, finance could only constitute part of a much more diverse production regime (Boyer, 2000). Moreover, change in one part of the system does not equate to systemic change. Boyer (2006) argues that aspects of the shareholder value model have infused Germany's mode of régulation; as other traditional aspects of the system, such as employment relations, have remained intact, a new configuration has emerged, but it remains distinct from the LME model. 
Recently, though, the régulation approach's primary concern has been to highlight the causes of the present-day crisis, and the mechanics of institutional redesign (Amable, 2017; Becker and Jäger, 2012; Boyer, 2011; Jessop, 2014c); indeed, régulation theory has increasingly questioned the possibility of bringing about alternatives to neo-liberalism, as key strands of HI have also done (Boyer, 2010; Jessop, 1989; Vidal, 2013). There has also been an increased and explicit focus on financialization, most notably by Boyer $(2000,2010,2011,2013)$, but by others as well (Becker and Jäger, 2012; Jessop, 2013, 2014b, 2014c). Although the literature on financialization is undeniably diverse and has many strands, including postmodernism, régulation theorists placed it within its broader historico-spatial context and saw it less as a departure from, and more as a reflection of inherent features of, capitalism (Westra, 2019).

For instance, the dynamics of capitalism has increased financialization in many countries, leading to a loss of informational content and enhancing systemic risks (Boyer, 2013b). Moreover, financial capital and inherited wealth are often misrepresented or repackaged as entrepreneurially generated; only through understanding how financial capital and inherited wealth are reproduced, is it possible to fully comprehend how they feed into job insecurity and income inequality, both in the creation and reproduction of vested interests as well as individual and collective life chances (Herlin-Giret, 2017; Mayer, 2016).

In general, the régulation approach is more overtly critical of neo-liberalism than the VoC/BST perspective (Boyer, 2005, 2010; Jessop, 2014a, 2014b). In addition and in common with HI, the approach suggests that capitalism's dynamics, acting through financial firms, shareholders and managers, leads to greater de-regulation and increased income inequality (Boyer, 2010, 2011; Jessop, 2014a; Mayer, 2016).For instance, 
reflecting régulationist thinking, Lazonick's (2017) work highlights how financialization has resulted, in the US, in speculative investments outweighing investment in production capabilities, leading to the decline of traditional large corporations capable of generating decent work, employment security and social equality (Urry, 2014). The régulation approach has, therefore, highlighted how common features of capitalism can explain increases in inequality and associated socio-political problems; however, it has tended to downplay the role of the state and diversity between different types of capitalism.

\section{Limits to liberalization?}

A common $\mathrm{CC}$ theme is that wealth generation requires some production process of goods or services. Hence, financialization primarily represents a process of wealth reallocation: highly fungible assets, and those assets that can readily be liquidated into highly fungible forms, are prioritized over non-fungible ones (Wood, 2013). The latter include not only money sunk into plant and machinery, and associated processes, but also organizations' human capabilities that are difficult to quantify (Hall and Soskice, 2001; Whitley, 1999).

Such developments help to explain why the LME model faces strong challenges and contradictions that other forms of capitalism do not (Wood, 2013; Wood and Wright, 2015). As recent global value chain theory highlights, greater outsourcing of production to low-wage economies has meant that dominant parties and intermediaries have been able to capture more of the value/wealth created by production (Pradella, 2017; Urry, 2014), at the expense of those involved in the actual production process who gained more from traditional, spatially contiguous production networks (Lane and Probert, 2009). Whilst resistance can sometimes prevent this process (Luthfa, 2017), in 
many instances, opposition may be difficult because of horizontal divisions and problems of co-ordination amongst countervailing actors (Lane and Probert, 2009). Outsourcing and offshoring can, therefore, diminish the process of production and labour's contribution, ultimately creating greater income and wealth inequality (de Thierry et al., 2014; Standing, 2011) as well as other forms of inequality within and between societies that are difficult to capture using nationally based measures alone (Urry, 2014).

In addition, social protection, which was already relatively weak in LMEs, has diminished further (Hay, 2011), increasing the stakes. Similarly, LMEs' over-inflated housing markets have made the property ladder inaccessible to growing numbers of individuals, especially those in younger generations, undermining the ability of houseprice increases to off-set income inequality (Bone and O'Reilly, 2010).

Mainstream politicians have often been unwilling or unable to offer policy alternatives to these challenges (Kuttner, 2007), resulting in socio-political blowback (Kalleberg, 2009) and the rise of right-wing populist politicians (Hopkin, 2017; Mayer, 2016), who have attained political power not only in many peripheral and emerging economies, but also in the two archetypical LMEs, the US and the UK. Despite posing as challengers to the establishment, such leaders are typically personally wealthy and aggressively rent seeking, and have secured the patronage of specific sub-segments of financial capital (Dörry and Dymski, n.d.). Whilst the populist right is a global phenomenon and have made headway in many countries, it has only captured power, amongst the mature LMEs and co-ordinated market economies (CMEs), in the US and the UK. Moreover, owing to a long period of political stability, the US's and the UK's political institutions, conceived of hundreds of years ago, may be particularly ill equipped to withstand a period of populism without lapsing into civil disorder or 
authoritarianism. From the late nineteenth century to the 1930 s, sociologists were much preoccupied with the relationship between constitutional legacies, and economic and political disorder (Durkheim, 1960; Henry, 1983; Levine, 1971). A long period of growth and stability does not mean that all within the financial and political elite become permanently wedded to democracy (Giroux and Bhattacharya, 2017).

\section{Discussion and Conclusions}

A prolonged period of uncertainty, volatility and stagnant real incomes for the majority has challenged, to varying degrees, $\mathrm{CC}$ contributions' initial assumptions on institutional stability and path dependence, leading to a growing consensus across the different strands of the CC literature on 1) the temporally specific and contingent nature of institutions and 2) the tensions between embedded, nationally distinct firm behaviours and common trends across the global capitalist ecosystem. In addition, a common argument is that developed economies are likely to experience increasing liberalization. Although the emphasis may vary, much of the existing $\mathrm{CC}$ literature highlights the increasing importance of labour-market systems (Greer and Doellgast, 2017; Thelen, 2014, 2019) and the 'restless nature' of capitalism itself (Boyer, 2013a; Morgan, 2016; Streeck, 2014b). We do not dispute the importance of these processes to explain increasing liberalization and, hence, rising inequality in many countries.

However, the evidence suggests that income and wealth inequality as well as social and employment security continue to vary significantly across developed countries. Existing analyses on advanced economies focus largely on market-based, or pre-tax and pre-transfer, inequalities, neglecting how states reduce inequality and how states vary in the degree to which they reduce inequality by. 
Although advanced economies have liberalized many aspects of their economies, the UK and the US have the highest levels of post-tax and post-transfer inequality. As noted above, the marketization of more areas of social life can weaken the social ties that markets need to function well in the first place (Polanyi, 2001; Sandel, 2012). That process may be underway in the UK and the US; however, much of the literature focuses on liberalization of other countries or regions (Baccaro and Benassi, 2017; Hall, 2018; Iversen and Soskice, 2013; Streeck, 2009; cf. Hay and Payne, 2015).These other countries may liberalize less if open-ended crisis increasingly characterizes the LME model.

The two largest liberal states' chronic inability not only to provide income and occupational security, but also to prevent declines in the material conditions of the bulk of their populations has led to a rise of populism in these countries (Froud et al., 2016; Hopkin, 2017; Inglehart and Norris, 2016). As theories of relative deprivation indicate (Runciman, 1966), poverty and inequality are often associated with compliance, but a significant worsening of material conditions increases notions of relative deprivation and the prospect of social unrest (Davies, 1962).

Right-wing populism's greater breadth and depth in the UK and US, compared to CMEs, and its relationship to income inequality, suggest the persistence of diverse outcomes (Hall, 2015a; Hay, 2011). Our analysis suggests three useful areas for future research. First, we need to analyse the causes of income inequality by extending existing theories that emphasize labour-market institutions, including unions and wage bargaining (Baccaro and Howell, 2017; Thelen, 2019). Such extensions could systematically analyse how the state and some firms influence inequality (Lain, 2016; Melling, 1991; Urry, 2014; Zhang and Whitley, 2013) as well as the broad patterns of society and social change that influence how that role varies both across countries and 
over time (Halford and Strangleman, 2009). There remains, therefore, a need for comparative studies to examine how institutions structure contrasting outcomes, including how various groups or classes experience work (Strangleman, 2017), both within and between different countries (Urry, 2014).

Second, studying the links between different models of capitalism and the role of (trans)national actors, on the one hand, and equality and socio-political outcomes, on the other, necessitates comparative analyses of the dynamic interplay between various actors, including elites, businesses, business associations, unions, charities, that may be largely regional, national or transnational in character (Luthfa, 2017; Morgan, 2016; Urry, 2014; Zhang and Whitley, 2013). Building on insights from fiscal sociology (Schumpeter, 1991 [1918]), such analyses could examine how the structure and power of elites, including multinational firms and large technology companies, influence states' abilities to tax them and how the elites' relative loyalty towards the systems that nurtured and serve them helped, in part, to increase right-wing populism in the UK and US (O'Reilly et al., 2016). The role of the German industrial foundations and families in supporting the German political and economic system, and likewise the Japanese zaibatsu, contrasts sharply to some sub-segments of the Anglophone financial elite, who have covertly funded far-right causes and sought to undermine social consensus (Giroux and Bhattacharya, 2017; Mayer, 2016). Yet, like their Weimar counterparts, they may battle to ensure the populists, whose rise they have facilitated, remain servile to their interests (O'Reilly et al., 2016). Such phenomena and trends should be set within an analysis of how different forms of capitalism interact with one another to weaken or support institutions, creating different opportunities for populist politicians to exploit (Hopkin, 2017) as well as making the case for internationally embedded analyses of largely national institutional systems (see Jessop, 2014a). 
Finally, the links between social inclusion, on the one hand, and social and political unrest and the rise of populism, on the other, remain unclear; yet these would appear to be of fundamental importance to understanding the development of different capitalisms. By emphasizing the range of social outcomes across different developed economies, our work suggests that future research should assess how social action and developments in political preferences shape institutions (Morgan, 2016). Such work would supplement existing research that focuses on the interactions between institutions, on the one hand, and firms and, for example, their investment and employment decisions, on the other. It would also lead to a greater understanding of the material conditions under which more sustainable models of capitalism emerge and prosper. Interestingly, CMEs have adopted renewable energy much more vigorously than have LMEs, where populist politicians have become shrill in their evangelization of hydrocarbons (Wood et al., n.d.). Exploring the interlinkages between stakeholder and environmental wellbeing, and how any counter movement from neo-liberal excess can deepen them, represents, therefore, a fertile area for future enquiry.

\section{Acknowledgements}

We would like to thank Daniel Kinderman, Christel Lane, Richard Whitley and the three anonymous referees for commenting on previous drafts of this paper. We are, of course, responsible for any errors that remain.

\section{References}

Amable B (2016) Institutional complementarities in the dynamic comparative analysis of capitalism. Journal of Institutional Economics 12(1): 79-103. 
Amable B (2017) Structural Crisis and Institutional Change in Modern Capitalism:

French Capitalism in Transition. Oxford: Oxford University Press.

Baccaro L and Benassi C (2014) Softening industrial relations institutions, hardening growth model: The transformation of the German political economy. Stato e mercato (3): 369-396.

Baccaro L and Benassi C (2017) Throwing out the ballast: growth models and the liberalization of German industrial relations. Socio-Economic Review 15(1): 85115.

Baccaro L and Howell C (2017) European Industrial Relations since the 1970s:

Trajectories of Neoliberal Transformation. Cambridge: Cambridge University Press.

Becker J and Jäger J (2012) Integration in crisis: A Regulationist perspective on the interaction of European varieties of capitalism. Competition and Change 16(3): $169-187$.

Benassi C, Doellgast V and Sarmiento-Mirwaldt K (2016) Institutions and inequality in liberalizing markets: Explaining different trajectories of institutional change in social Europe. Politics \& Society 44(1): 117-142.

Bone J and O'Reilly K (2010) No place called home: The causes and social consequences of the UK housing 'bubble'. British Journal of Sociology 61(2): $231-255$.

Boyer R (1990) The Regulation School: A Critical Introduction. New York: Columbia University Press.

Boyer R (2000) Is a finance-led growth regime a viable alternative to Fordism? A preliminary analysis. Economy and Society 29(1): 111-145. 
Boyer R (2004) New growth regimes, but still institutional diversity. Socio-Economic Review 2(1): 1-32.

Boyer R (2005) How and why capitalisms differ. Economy and Society 34(4): 509-557.

Boyer R (2010) The collapse of finance but labour remains weak. Socio-Economic Review 8: 348-353.

Boyer R (2011) Are there laws of motion of capitalism? Socio-Economic Review 9(1): $59-81$.

Boyer R (2013a) The euro crisis: Undetected by conventional economics, favoured by nationally focused polity. Cambridge Journal of Economics 37(3): 533-569.

Boyer R (2013b) The global financial crisis in historical perspective: An economic analysis combining Minsky, Hayek, Fisher, Keynes and the Regulation Approach. Accounting, Economics and Law 3(3): 93-139.

Bukodi E and Paskov M (2018) Income inequality, living standards and intergenerational social mobility. In: Nolan B (ed.) Generating Prosperity for Working Families in Affluent Countries. Oxford: Oxford University Press, pp. $335-355$.

Coates D (2015) Varieties of Capitalism and 'the Great Moderation'. In: Ebenau M, Bruff I, and May C (eds) New Directions in Comparative Capitalisms Research: Critical and Global Perspectives. Houndsmill: Palgrave Macmillan, pp. 11-27.

Crouch C (2013) Making Capitalism Fit for Society. Cambridge: Polity Press.

Crouch C (2014) The governance of labour market insecurity during the crisis. Stato e Mercato (1): 69-86.

Crouch C (2016) The Knowledge Corrupters: Hidden Consequences of the Financial Takeover of Public Life. Cambridge: Polity Press. 
Davies JC (1962) Toward a theory of revolution. American Sociological Review 27(1): $5-19$

Davis GF and Kim S (2015) Financialization of the economy. Annual Review of Sociology 41(1): 203-221.

de Thierry E, Lam H, Harcourt M, et al. (2014) Defined benefit pension decline: The consequences for organizations and employees. Employee Relations 36(6): 654673.

Deeg R (2012) The limits of Liberalization? American capitalism at the crossroads. Journal of European Public Policy 19(8): 1249-1268.

Dewenter KL and Malatesta PH (2001) State-owned and privately owned firms: An empirical analysis of profitability, leverage, and labor intensity. The American Economic Review 91(1): 320-334.

Djankov S, Glaeser E, La Porta R, et al. (2003) The new comparative economics. Journal of Comparative Economics 31(4): 595-619.

Dore R (2000) Stock Market Capitalism: Welfare Capitalism: Japan and Germany versus the Anglo-Saxons. Oxford, UK: Oxford University Press.

Dorling D (2018) Inequality: Britain's Ticking Time Bomb. Bristol: Policy Press. Dörry S and Dymski G (n.d.) Will Brexit reverse the centralizing momentum of global finance? Geoforum.

Durkheim E (1960) The Division of Labor in Society. Glencoe, IL: The Free Press of Glencoe.

Emmenegger P and Marx P (2011) Business and the development of job security regulations: The case of Germany. Socio-Economic Review 9(4): 729-756.

Froud J, Johal S and Williams K (2016) Multiple economies: Before and after Brexit. Socio-Economic Review 14(4): 814-819. 
Gamble A (2014) Crisis without End? The Unravelling of Western Prosperity.

Basingstoke: Palgrave Macmillan.

Giddens A (1970) Marx, Weber and the development of capitalism. Sociology 4(3): $289-310$.

Giroux HA and Bhattacharya D (2017) Anti-politics and the scourge of authoritarianism. Social Identities 23(5): 503-517.

Goldthorpe JH (2010) Analysing social inequality: A critique of two recent contributions from economics and epidemiology. European Sociological Review 26(6): 731-744

Greer I and Doellgast V (2017) Marketization, inequality, and institutional change:

Toward a new framework for comparative employment relations. Journal of Industrial Relations 59(2): 192-208.

Haberly D (2014) Wealth fund investment and the evolution of German industrial finance. Economic Geography 90(3): 293-319.

Halford S and Savage M (2017) Speaking sociologically with big data: Symphonic social science and the future for big data research. Sociology 51(6): 1132-1148.

Halford S and Strangleman T (2009) In search of the sociology of work: Past, present and future. Sociology 43(5): 811-828.

Hall PA (2015a) The Changing Role of the State in Liberal Market Economies. In: Leibfried S, Nullmeier F, Huber E, et al. (eds) The Oxford Handbook of Transformations of the State. Oxford: Oxford University Press, pp. 426-444.

Hall PA (2015b) Varieties of Capitalism. In: Scott R and Kosslyn S (eds) Emerging Trends in the Social and Behaviror Science. John Wiley and Sons, pp. 1-15.

Hall PA (2018) Varieties of capitalism in light of the euro crisis. Journal of European Public Policy 25(1): 7-30. 
Hall PA and Soskice D (2001) An introduction to varieties of capitalism. In: Hall PA and Soskice D (eds) Varieties of Capitalism: The Institutional Foundations of Comparative Advantage. Oxford: Oxford University Press, pp. 1-56.

Hall PA and Thelen K (2009) Institutional change in varieties of capitalism. Socio Economic Review 7(1): 7-34.

Hay C (2011) Pathology without crisis? The strange demise of the Anglo-liberal growth model. Government and Opposition 46(1): 1-31.

Hay C (2013) The Failure of Anglo-Liberal Capitalism. Basingstoke: Palgrave Macmillan.

Hay C and Payne A (2015) Civic Capitalism. Cambridge: Polity Press.

Henry S (1983) Private Justice: Towards Integrated Theorising in the Sociology of Law. London: Routledge.

Herlin-Giret C (2017) Quand les héritiers deviennent des ‘entrepreneurs': les nouveaux appuis rhétoriques et pratiques de l'accumulation. Revue de la régulation 22(2).

Hollingsworth JR and Boyer R (1997) Coordination of economic actors and social systems of production. In: Contemporary Capitalism: The Embeddedness of Institutions. Cambridge: Cambridge University Press, pp. 1-47.

Hopkin J (2017) When Polanyi met Farage: Market fundamentalism, economic nationalism, and Britain's exit from the European Union. The British Journal of Politics and International Relations 19(3): 465-478.

Inglehart RF and Norris P (2016) Trump, Brexit, and the Rise of Populism: Economic Have-Nots and Cultural Backlash. Harvard Kennedy School of Government Faculty Research Working Paper Series. 
Iversen T and Soskice D (2013) An structural-institutional explanation of the Eurozone crisis. Presented at the Political Economy Workshop at the London School of Economics and Political Science, June 3. Cambridge, MA.

Jackson G and Deeg R (2008) From comparing capitalisms to the politics of institutional change. Review of International Political Economy 15(4): 680-709. Jessop B (1989) Neo-conservative regimes and the transition to post-Fordism. In: Gottdiener M and Komninos N (eds) Capitalist Development and Crisis Theory Accumulation, Regulation, and Spatial Restructuring. Basingstoke: Macmillan, pp. 261-299.

Jessop B (1990) Regulation theories in retrospect and prospect. Economy and Society 19(2): 153-216.

Jessop B (1997) Capitalism and its future: Remarks on regulation, government and governance. Review of International Political Economy 4(3): 561-581. Jessop B (2001) Series Preface. In: Regulation Theory and the Crisis of Capitalism Volume 4: Country Studies. Cheltenham: Edward Elgar, pp. xxv-xxxviii. Jessop B (2012) The world market, variegated capitalism, and the crisis of European integration. In: Nousios P, Overbeek H, and Tsolakis A (eds) Globalisation and European Integration: Critical Approaches to Regional Order and International Relations. New York: Routledge, pp. 91-111.

Jessop B (2013) Finance Dominated Accumulation and Post Democratic Capitalism. In: Fadda S and Tridico P (eds) Institutions and Economic Development after the Financial Crisis. Abingdon: Routledge, pp. 83-105.

Jessop B (2014a) Capitalist diversity and variety: Variegation, the world market, compossibility and ecological dominance. Capital \& Class 38(1): 45-58. 
Jessop B (2014b) Financialization, financial crisis and deficit hysteria: neo-liberalism redux. In: Panizza F and Philip G (eds) Moments of Truth: The Politics of Financial Crises in Comparative Perspective. London: Routledge, pp. 101-119. Jessop B (2014c) Variegated Capitalism, das Modell Deutschland, and the Eurozone Crisis. Journal of Contemporary European Studies.

Kalleberg AL (2009) Precarious work, insecure workers: Employment relations in transition. American Sociological Review 74(1): 1-22.

Kinderman D (2017) Challenging varieties of capitalism's account of business interests: Neoliberal think-tanks, discourse as a power resource and employers' quest for liberalization in Germany and Sweden. Socio-Economic Review 15(3): 587-613. Kristensen PH and Morgan G (2018) Danish foundations and cooperatives as forms of corporate governance: Origins and impacts on firm strategies and societies. In: Boeger N and Villiers C (eds) Shaping the Corporate Landscape: Towards Corporate Reform and Enterprise Diversity. London: Hart Publishing, pp. 271288.

Kuttner R (2007) The Squandering of America: How the Failure of Our Politics Undermines Our Prosperity. New York: Alfred A. Knopf.

Lain D (2016) Reconstructing Retirement: Work and Welfare in the UK and USA. Bristol: Polity Press.

Lane C (1989) From ‘welfare capitalism' to 'market capitalism': A comparative review of trends towards employment flexibility in the labour market of three major European societies. Sociology 23(4): 583-610.

Lane C and Probert J (2009) National Capitalisms, Global Production Networks: Fashioning the Value Chain in the UK, US, and Germany. Oxford, UK: Oxford University Press. 
Lavery S (2018) The legitimation of post-crisis capitalism in the United Kingdom: Real wage decline, finance-led growth and the state. New Political Economy 23(1): $27-45$.

Lazonick W (2017) The new normal is "maximizing shareholder value": Predatory value extraction, slowing productivity, and the vanishing American middle class. International Journal of Political Economy 46(4): 217-226.

Levine DN (ed.) (1971) Georg Simmel on Individuality and Social Forms. Chicago: Chicago University Press.

Lincoln JR and Kalleberg AL (1990) Culture, Control and Commitment: A Study of Work Organization in the United States and Japan. Cambridge: Cambridge University Press.

Lipietz A (1993) From Althusserianism to 'regulation theory'. In: Kaplan EA and Sprinker M (eds) The Althusserian Legacy. London, UK: Verso, pp. 99-138.

Luthfa S (2017) Transnational ties and reciprocal tenacity: Resisting mining in Bangladesh with transnational coalition. Sociology 51(1): 127-145.

Mayer J (2016) Dark Money: The Hidden History of the Billionaires behind the Rise of the Radical Right. New York: Doubleday.

Melling J (1991) Industrial capitalism and the welfare of the state: The role of employers in the comparative development of welfare states. A review of recent research. Sociology 25(2): 219-239.

Morgan G (2005) Introduction: Changing capitalisms? Internationalization, institutional change, and systems of economic organization. In: Morgan G, Whitley R, and Moen E (eds) Changing Capitalisms? Internationalization, Institutional Change, and Systems of Economic Organization. Oxford: Oxford University Press, pp. 118. 
Morgan G (2014) Financialization and the multinational corporation. Transfer:

European Review of Labour and Research 20(2): 183-197.

Morgan G (2015) Elites, Varieties of Capitalism and the crisis of neo-liberalism. In:

Morgan G, Hirsch P, and Quack S (eds) Elites on Trial: Research in the Sociology of Organizations. Bingley: Emerald, pp. 55-80.

Morgan G (2016) New actors and old solidarities: Institutional change and inequality under a neo-liberal international order. Socio-Economic Review 14(1): 201-225. Morgan G and Kristensen PH (2014) The comparative analysis of capitalism and the study of organizations. In: Adler P, du Gay P, Morgan G, et al. (eds) The Oxford Handbook of Sociology, Social Theory, and Organization Studies: Contemporary Currents. Oxford: Oxford University Press, pp. 220-245.

Morgan G and Whitley R (2012) Capitalisms and capitalism in the twenty-first century: Introduction. In: Morgan G and Whitley R (eds) Capitalisms and Capitalism in the Twenty-First Century. Oxford: Oxford University Press, pp. 1-10.

O’Reilly J, Froud J, Johal S, et al. (2016) Brexit: understanding the socio-economic origins and consequences. Socio-Economic Review 14(4): 807-854.

Parsons T (1929) 'Capitalism’ in recent German literature: Sombart and Weber (concluded). The Journal of Political Economy 37(1): 31-51.

Polanyi K (2001) The Great Transformation: The Political and Economic Origins of Our Time. Boston: Beacon Press.

Pradella L (2017) Marx and the global South: Connecting history and value theory. Sociology 51(1): 146-161.

Regini M (2014) Models of capitalism and the crisis. Stato e mercato (1): 21-44. Runciman WG (1966) Relative Deprivation and Social Justice. London: Routledge and Kegan Paul. 
Sandel M (2012) What Money Can't Buy: The Moral Limits of Markets. London: Allen Lane.

Schumpeter JA (1991) The Crisis of the Tax State. In: Swedberg R (ed.) Joseph A. Schumpeter, The Economics and Sociology of Capitalism. Princeton: Princeton University Press, pp. 99-140.

Seeleib-Kaiser M (2016) The end of the conservative German welfare state model.

Social Policy and Administration 50(2): 219-240.

Standing G (2011) The Precariat: The New Dangerous Class. London, UK: Bloomsbury Academic.

Steinmo S and Thelen K (1992) Historical institutionalism in comparative politics. In:

Steinmo S, Thelen K, and Longstreth F (eds) Structuring Politics: Historical Institutionalism in Comparative Analysis. Cambridge: Cambridge University Press, pp. 1-32.

Strangleman T (2017) Deindustrialisation and the historical sociological imagination:

Making sense of work and industrial change. Sociology 51(2): 466-482.

Streeck W (2009) Re-Forming Capitalism: Institutional Change in the German Political Economy. Oxford, UK: Oxford University Press.

Streeck W (2012) How to study contemporary capitalism? European Journal of Sociology 53(1): 1-28.

Streeck W (2013) Gekaufte Zeit: Die Vertagte Krise Des Demokratischen Kapitalismus. Berlin: Suhrkamp Verlag.

Streeck W (2014a) How will capitalism end? New Left Review 87(May/June): 35-64. Streeck W (2014b) Taking crisis seriously: Capitalism on its way out. Stato e mercato (1): 45-67. 
Streeck W (2016) On the dismal future of capitalism. Socio-Economic Review 14(1): $164-170$.

Thelen K (1999) Historical institutionalism in comparative politics. Annual Review of Political Science 2(1): 369-404.

Thelen K (2012) Varieties of capitalism: Trajectories of liberalization and the new politics of social solidarity. Annual Review of Political Science 15(1): 137-159.

Thelen K (2014) Varieties of Liberalization and the New Politics of Social Solidarity. Cambridge: Cambridge University Press.

Thelen K (2019) The American precariat: U.S. capitalism in comparative perspective. Perspectives on Politics: 1-23.

Urry J (2014) Offshoring. Cambridge: Polity Press.

Vidal M (2013) Postfordism as a dysfunctional accumulation regime: a comparative analysis of the USA, the UK and Germany. Work, Employment \& Society 27(3): $451-471$.

Watson TJ (2009) Work and the sociological imagination: The need for continuity and change in the study of continuity and change. Sociology 43(5): 861-877.

Weber M (2001) The Protestant Ethic and the Spirit of Capitalism. London: Routledge. Westra R (2019) Problematizing capitalism in the era of globalization and financialization. In: Periodizing Capitalism and Capitalist Extinction. London: Palgrave Macmillan, pp. 179-214.

Whitley R (1999) Divergent Capitalisms: The Social Structuring and Change of Business Systems. Oxford, UK: Oxford University Press.

Whitley R (2003) The institutional structuring of organizational capabilities: The role of authority sharing and organizational careers. Organization Studies 24(5): 667695. 
Whitley R (2012) Internationalization and the institutional structuring of economic organization: Changing authority relations in the twenty-first century. In: Morgan G and Whitley R (eds) Capitalisms and Capitalism in the Twenty-First Century. Oxford, UK: Oxford University Press, pp. 211-236.

Wilkinson R and Pickett K (2009) The Split Level: Why Greater Equality Makes Societies Stronger. London: Penguin.

Williams M (2017) Occupational stratification in contemporary Britain: Occupational class and the wage structure in the wake of the Great Recession. Sociology 51(6): $1299-1317$.

Wood G (2013) Institutional diversity: Current contestations and emerging issues. The Journal of Comparative Economic Studies 8(1): 7-20.

Wood G (2015) Structural crisis and transitions: Present issues and potential future trajectories. Journal of Comparative Economic Studies 10(1): 55-68.

Wood G and Wright M (2015) Corporations and new statism: Trends and research priorities. Academy Management Perspectives 29(2): 271-286.

Wood G, Finnegan JJ, Allen ML, et al. (n.d.) The comparative institutional analysis of energy transitions. Socio-Economic Review. DOI: 10.1093/ser/mwz040.

Zhang X and Whitley R (2013) Changing macro-structural varieties of East Asian capitalism. Socio-Economic Review 11(2): 301-336. 


\section{Author biographies}

Professor Geoffrey Wood is Dancap Chair of Innovation, Professor of Sociology and Head of DAN Management at Western University, Canada, and Visiting Professor at Trinity College, Dublin. Previously, he served as Dean and Professor of International Business, Essex Business School and as Professor of International Business, Warwick Business School. He has authored/co-authored/edited 18 books, and over 180 articles in peer-reviewed journals. He holds honorary positions at Griffith and Monash universities, Australia, and Witwatersrand and Nelson Mandela universities, South Africa. Geoff's research focuses on the relationship between institutional setting, corporate governance, firm finance, and firm level work and employment relations.

Matthew Allen is Professor of International Business and Strategy and Head of the Management Science and Entrepreneurship Group, Essex Business School. He has published in leading comparative and international business journals, such as the British Journal of Management, Socio-Economic Review and the International Journal of Human Resource Management. He is on the editorial board of the International Journal of Human Resource Management. He has gain funding for his research from the German Academic Exchange Service, the Fritz Thyssen Foundation, and the Engineering and Physical Sciences Research Council. His research examines how different types of capitalism influence work and innovation. 
Figure 1 Gini Coefficients before and after taxes and transfers, 2008

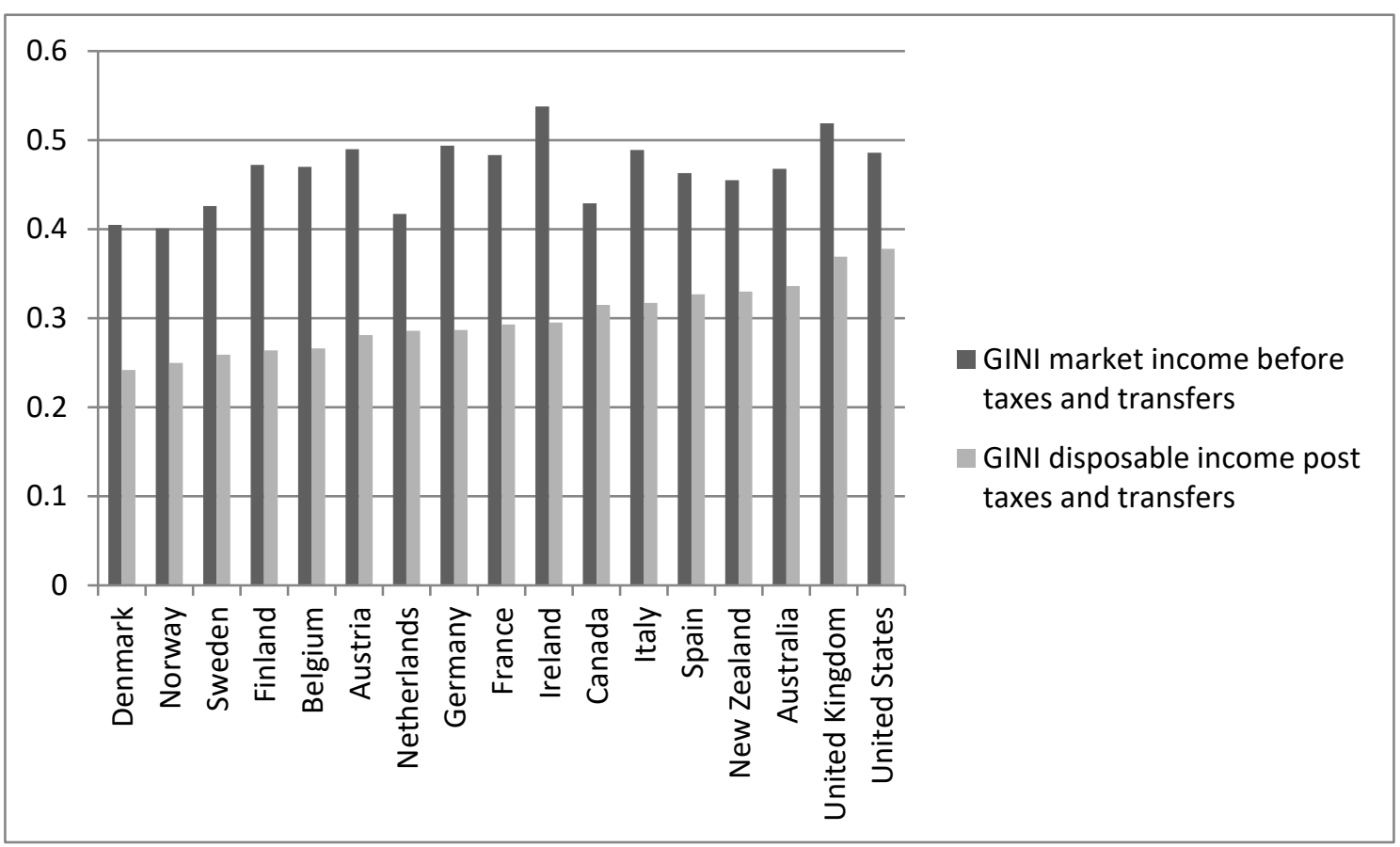

Source: OECD

Notes: The Gini coefficient compares cumulative proportions of the population against cumulative proportions of income they receive, and it ranges between 0 in the case of perfect equality and 1 in the case of perfect inequality. 
Figure 2 Gini Coefficients before and after taxes and transfers, 2016

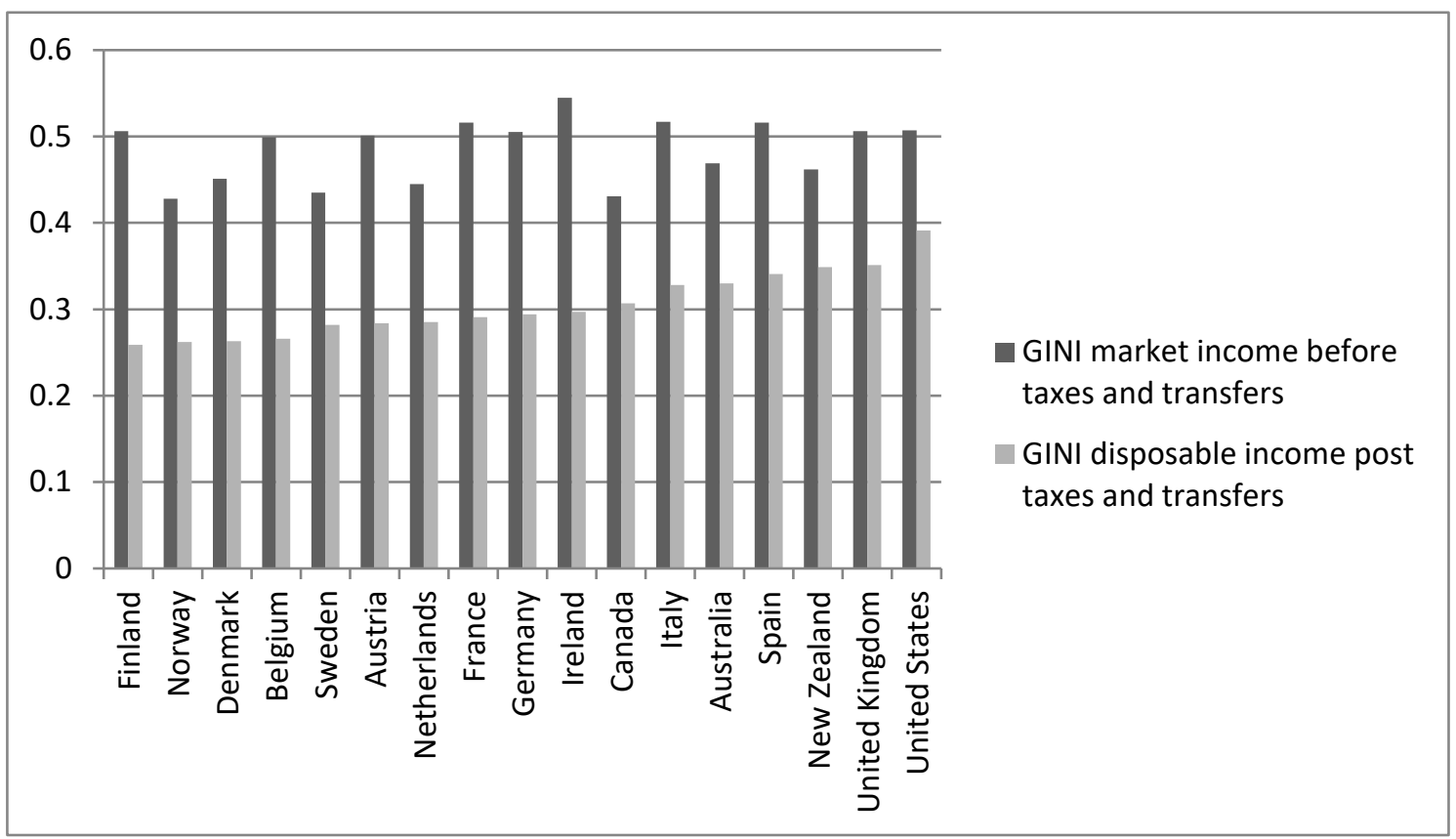

Source: OECD

Notes: Data are for 2016, except: Denmark 2015, Ireland 2015, and New Zealand 2014. 